
\title{
Biologists moot daunting plan to track viruses
}

Jonathan Knight, San Francisco, and Alison Abbott, Munich

Three US researchers have proposed an ambitious project to sequence the genetic code of every virus known to infect humans. They plan to use the information in a database to track new and emerging viral infections. But critics say that it is not always possible to tell harmful and benign viruses apart, and that such a system could generate numerous false alarms.

The proposal, to be published in the July issue of Emerging Infectious Diseases, would involve collecting viral particles from blood plasma from a variety of sources, including the Red Cross and hospital labs. The genetic material would then be extracted and sequenced, and a database built up.

Methods for using centrifugation to purify viruses from large volumes of plasma were developed in the 1960s by the proposal's principal author, Norman Anderson, president of the Viral Defense Foundation based in Kensington, Maryland. Once fully automated, the sequencing process should be rapid enough to spot new viruses within days of obtaining blood samples, he says.

Anderson developed the proposal with his son Leigh, who is chief executive of the Plasma Proteome Institute, a Washingtonbased organization that promotes protein research, and John Gerin, director of the molecular virology and immunology division at Georgetown University Medical Center in Rockville, Maryland. Although the plan is in its early stages and has not yet been costed, the sequencing of viruses en masse

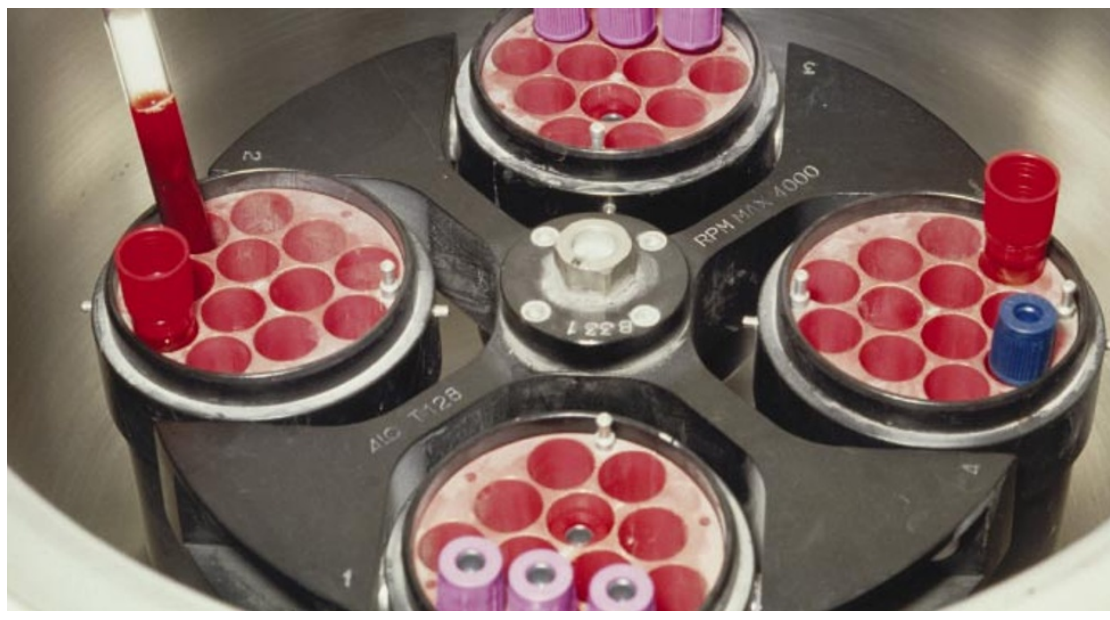

In a spin: centrifuges will be key for separating viral particles from blood samples for genetic analysis.

has already been achieved in marine biology. A team at San Diego State University, which is collaborating with Anderson, last year sequenced hundreds of viruses from the Pacific Ocean (M. Breitbart et al. Proc. Natl Acad. Sci. USA 99, 14250-14255;2002).

Anderson's scheme will face additional technological challenges. The marine viruses had DNA genomes, but the genomes of most human viruses are made up of RNA. This adds an extra step to the sequencing process, as the RNA must be converted into DNA.

Even if the project is feasible, others say that the real challenge will be interpreting the information. "You will end up with a lot of results that cannot be linked to disease," says Christian Drosten, a virologist at the Bernhard
Nocht Institute for Tropical Medicine in Hamburg, Germany. The people from whom the blood was taken would have to be screened to see if their immune systems were reacting to a new virus, which would slow the tracking process considerably, says Drosten. Spotting new viruses in blood could also lead to unnecessaryblood-supply scares, he adds.

Anderson says that such concerns can be overcome. He believes the danger of new viruses could be assessed by monitoring epidemiological reports from the regions in which they emerge. The system could also help to solve a number of disease puzzles, he adds, as the database would allow researchers to spot correlations between viruses and diseases that are not completely understood.

\section{Threat of closure hangs heavy over primate centre}

\section{Rex Dalton, San Diego}

The future of the Duke University Primate Center in Durham, North Carolina, considered by evolutionary biologists to be

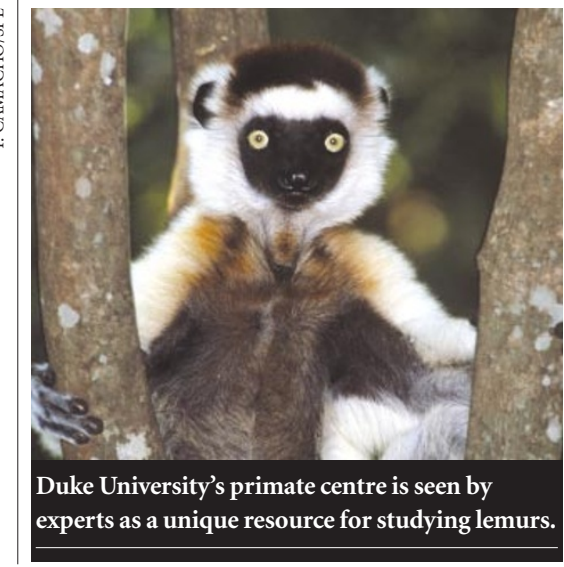

unique and irreplaceable, is hanging in the balance. Administrators at Duke University could decide within a month not to seek a new permanent director and to phase the animal centre out of existence.

The decision will come at the end of an 18-month review period triggered by criticism that the facility had too many animals but carried out too little research. Duke officials sought to reorient the centre towards teaching and research, rather than conservation, and Duke officials say that it has improved. The colony has fallen from a peak of more than 600 animals to about 250 , following the introduction of tight reproductive controls and a move to donate excess animals to zoos.

The Duke centre is home to the world's primary research colony of living prosimians, a branch of primates that evolved 50 million years before apes and monkeys. Often dubbed 'living fossils', the centre's prosimians, mostly lemurs, provide researchers with an unmatched resource for studying aspects of early primate evolution, from blood chemistry to morphology. "The centre is a gem beyond compare," says Anne Yoder, an evolutionary biologist at Yale University in New Haven, Connecticut.

Elwyn Simons, a palaeontologist at Duke, says that about 50 projects studying living lemurs are under way, with about 40 projects involving the facility's prosimian fossil collection. "We are very impressed with the ramping up of research," says Jim Siedow, Duke's vice-provost for research.

The facility, which was created in the 1960s and has an annual operating budget of about \$1.2 million, could probably not be duplicated because some prosimian species are now endangered. Lemurs live in the wild only in Madagascar, where they are on the brink of extinction. 